\title{
Metformin (dimethyl-biguanide) induced DNA damage in mammalian cells
}

\author{
Rubem R. Amador ${ }^{1}$, João Paulo Figueiró Longo ${ }^{1 *}$, Zulmira G. Lacava ${ }^{1}$, José G. Dórea ${ }^{2}$ \\ and Maria de Fátima M. Almeida Santos ${ }^{1}$ \\ ${ }^{1}$ Departamento de Genética e Morfologia, Instituto de Ciências Biológicas, Universidade de Brasília, \\ Brasília, DF, Brazil. \\ ${ }^{2}$ Departamento de Nutrição, Faculdade de Ciências da Saúde, Universidade de Brasília, Brasília, \\ DF, Brazil.
}

\begin{abstract}
Metformin (dimethyl-biguanide) is an insulin-sensitizing agent that lowers fasting plasma-insulin concentration, wherefore it's wide use for patients with a variety of insulin-resistant and prediabetic states, including impaired glucose tolerance. During pregnancy it is a further resource for reducing first-trimester pregnancy loss in women with the polycystic ovary syndrome. We tested metformin genotoxicity in cells of Chinese hamster ovary, CHO-K1 (chromosome aberrations; comet assays) and in mice (micronucleus assays). Concentrations of $114.4 \mu \mathrm{g} / \mathrm{mL}$ and $572 \mu \mathrm{g} / \mathrm{mL}$ were used in in vitro tests, and $95.4 \mathrm{mg} / \mathrm{kg}, 190.8 \mathrm{mg} / \mathrm{kg}$ and $333.9 \mathrm{mg} / \mathrm{kg}$ in assaying. Although the in vitro tests revealed no chromosome aberrations in metaphase cells, DNA damage was detected by comet assaying after $24 \mathrm{~h}$ of incubation at both concentrations. The frequency of DNA damage was higher at concentrations of $114.4 \mu \mathrm{g} / \mathrm{mL}$. Furthermore, although mortality was not observed in in vitro tests, the highest dose of metformin suppressed bone marrow cells. However, no statistically significant differences were noted in micronuclei frequencies between treatments. In vitro results indicate that chronic metformin exposure may be potentially genotoxic. Thus, pregnant woman undergoing treatment with metformin should be properly evaluated beforehand, as regards vulnerability to DNA damage.
\end{abstract}

Key words: metformin, DNA damage, chromosome aberration.

Received: April 18, 2011; Accepted: August 27, 2011.

\section{Introduction}

Metformin (dimethyl-biguanide) is an insulin-sensitizing agent that lowers fasting plasma insulin concentrations by increasing the peripheral uptake of glucose and decreasing hepatic glucose output (Nisbet et al., 2004). It is prescribed for patients suffering from a variety of insulin-resistant and prediabetic states, including impaired glucose tolerance, obesity (Tankova et al., 2003; Rotella et al., 2006; Hirsch et al., 2009) and metabolic abnormalities associated with HIV disease (Hadigan et al., 2000; Johnson et al., 2005; Diehl et al., 2008). Furthermore, metformin is also used regulating anovulation, and induce and sustain pregnancy in polycystic-ovary syndrome patients (Jakubowicz et al., 2002; De Leo et al., 2006; Lilja and Mathiesen, 2006; Brassard et al., 2008).

The toxicity of metformin is well-known in cases of metabolic impairment due to liver and kidney diseases, its toxicity, by being mainly associated with lactic acidosis,

Send correspondence to João Paulo Figueiró Longo. Universidade de Brasília, Campus Universitário Darcy Ribeiro, Instituto de Ciências Biológicas, Bloco 8, 70910-970 Brasília, DF, Brazil. E-mail: jplongo82@gmail.com. can occur through both acute and chronic exposure (DePalo et al., 2005; Strack, 2008). Secondary to metforminassociated lactic acidosis, patients may undergo alterations in the central nervous system, cardiovascular collapse, renal failure, and eventually, death (Snyder and Berns, 2004; Spiller and Sawyer, 2006). Nonetheless, non-clinical or metabolic outcomes, possibly associated with genotoxic effects, have not received due consideration. Results from the few experimental in vivo and in vitro studies so far undertaken are controversial. While some reports indicated no genotoxic effects (Attia et al., 2009), others (Janjetovic et $a l ., 2011$ ) have assumed that metformin can produce oxidative stress due to DNA fragmentation. Onaran et al. (2006) proposed that high concentrations of metformin increased cumene hydroperoxide (CumOOH)-induced DNA damage. Furthermore, Anedda et al., (2008) showed that metformin induces oxidative stress in white adipocytes, by|through increasing the levels of reactive oxygen species, and reducing aconitase activity.

Various drugs are capable of damaging the DNA in living cells. If not repaired, or if produced in excessive amounts, DNA damage can initiate a cascade of biological effects (cellular, organic, individual), the most outstanding 
consequence being carcinogenesis (Moustacchi, 2000; Barash et al., 2010). Therefore, on considering the enhanced association between the chronic use of certain drugs and the increase in DNA damage, the aim of the current study was to evaluate metformin genotoxicity.

\section{Materials and Methods}

\section{Chemicals}

Metformin was commercially obtained as metformin hydrochloride $500 \mathrm{mg}$ (Merck S.A.). Before using, the drug was dissolved in Dulbecco modified Eagle medium (DMEM) at determined experimental concentrations.

\section{In vitro test}

\section{Cell and culture conditions}

Chinese hamster ovary (CHO-K1) cells were grown at $37{ }^{\circ} \mathrm{C}$, in an atmosphere of $5 \%$ of $\mathrm{CO}_{2}$ in DMEM, (GIBCO-BRL), at $\mathrm{pH} 7.4$, and supplemented with $10 \%$ fetal calf serum. The CHO-K1 cells $\left(3.5 \times 10^{5}\right)$ were seeded into $25 \mathrm{~cm}^{2}$ tissue culture flasks and stabilized for $24 \mathrm{~h}$. All the experiments were run in triplicate.

Cell viability analysis with trypan blue exclusion testing was to determine the metformin dosage necessary to kill $50 \%$ of the cells (lethal concentration 50, LC50). On considering previous studies, lower dosages of LC50, viz., $15 \%(114.4 \mu \mathrm{g} / \mathrm{mL})$ and $80 \%(572 \mu \mathrm{g} / \mathrm{mL})$, were employed for evaluating genotoxicity.

Experimental groups consisted of cells treated with metformin (114.4 and $572 \mu \mathrm{g} / \mathrm{mL}$ ). Negative controls consisted of untreated cultures and positive control (cyclophosphamide at $6 \mu \mathrm{g} / \mathrm{mL}$ ) groups. After treatment for $24 \mathrm{~h}$, each culture was washed, harvested, re-suspended in PBS and used for the comet assay and chromosome aberration testing.

\section{Comet assay}

The comet assay (alkaline) described by Singh et al. (1988) was used with certain modifications. Briefly, $30 \mu \mathrm{L}$ of cell suspension $\left(10^{5}-10^{6}\right.$ cells $)$ were mixed with $120 \mu \mathrm{L}$ of low melting point agarose $(0.5 \%$ in PBS buffer) and added to slides that had been previously covered with a layer of type II agarose (1.5\% in PBS buffer). The slides (without coverslips) were immersed in cold lysing solution (2.5 M NaCl, 0.1 M EDTA, 0.01 M Tris and 1X Triton $\mathrm{X}-100)$ for $1 \mathrm{~h}$ at $4{ }^{\circ} \mathrm{C}$. They were then placed into an electrophoresis solution $(300 \mathrm{mM} \mathrm{NaOH}, \mathrm{pH} 13,1 \mathrm{mM}$ EDTA,) for $20 \mathrm{~min}$, at $25 \mathrm{~V}$ and $300 \mathrm{~mA}$. After electrophoresis, the slides were neutralized in $0.4 \mathrm{M}$ Tris buffer (pH 7.5), stained with $50 \mu \mathrm{L}$ ethidium bromide $(20 \mu \mathrm{g} / \mathrm{mL}$; Sigma), and analyzed using a fluorescence microscope (Carl Zeiss) at 400X equipped with exciting (515-560-nm) and barrier (590-nm) filters.
Approximately 300 randomly chosen cells per experimental point (100 per replicate slide) were analyzed. DNA damage category was assigned to five classes (0-4), based on the visual aspect of the comets, and considering the extent of DNA migration in accordance with Visvardis et al. (1997). Nucleoids with a bright head and no tail were classified as class 0 (undamaged nucleoids), whereas highly damaged ones, with a small head and a long diffuse tail, as class 4 . Those presenting intermediate characteristics were classified as classes 1,2 or 3. Index of DNA damage (IDD) was quantified using the equations described by Jaloszynski et al. (1997):

$$
\operatorname{IDD}=\frac{\left(n_{1}+2 n_{2}+3 n_{3}+4 n_{4}\right)}{(\Sigma / 100)}
$$

where IDD is DNA damage in arbitrary units, $n_{1}-n_{4}$ the number of class 1 to 4 comets and $\Sigma$ the total number of scored nucleoids, including class 0 . IDD values ranged from 0 (all undamaged nucleoids) to 400 (all maximally damaged nucleoids) arbitrary units, each of which was converted to a percentage of damaged DNA, with the total score of 400 representing $100 \%$ damage.

\section{Metaphase preparation}

Chromosome aberrations were carried out according to our own routine procedures (Almeida Santos et al., 2005). Briefly, in all the treatments, colchicine $4 \%\left(10^{5} \mathrm{M}\right)$ was added to the culture $2 \mathrm{~h}$ before harvesting. After harvesting, the cells were treated with a $0.075 \mathrm{M} \mathrm{KCl}$ hypotonic solution for $20 \mathrm{~min}$ at $37^{\circ} \mathrm{C}$, fixed three times in methanol-acetic acid (3:1), and slides prepared. These were stained with $10 \%$ Giemsa in a phosphate buffer $(\mathrm{pH} 6.8)$ for 10 min. 1556 metaphases (200 metaphases from each parallel culture) were analyzed per treatment. Blind analysis was through cytogenetic assaying. Cells with chromosome aberrations, such as gaps, breaks and acentric fragments, i.e., fragments of chromosomes without centromeres, were recorded. The standard cytogenetic procedures established by the Chatham Bars Inn Conference (CBIC system) were adopted, i.e., a chromatid lesion whose length was less than the diameter of the chromatid itself was classified as a chromatid gap, whereas, that whose length was equal to or greater than the diameter was regarded as a chromatid break.

\section{In vivo test}

All animal handling and procedures were carried out according to the international practices for animal use and care, and approved by the Animal Ethics Committee of the University of Brasilia. Female Swiss albino mice (10-12 weeks old) weighing 25-30 g were obtained from the Central Animal Facility of the University of Brasilia. 100 animals were acclimatized to laboratory conditions for one week prior to starting the study; they were provided with Purina mice chow and filtered water ad libitum. Following 
acclimatization, they were randomly divided into groups (10 each) for acute toxicity testing to determine the median lethal dose (LD50), 7 days after an intraperitoneal (i.p.) injection. The Trimed Sperman-Karber method was used, whereby LD50 value was defined as $477 \mathrm{mg} / \mathrm{kg}$. The metformin concentrations represented respectively $20 \%$, $40 \%$, and $70 \%$ of the LD50, and were given in the form of i.p. injections in a $0.5 \mathrm{~mL}$ volume.

For the genotoxicity experiment, 40 animals were randomly divided into five groups ( 8 in each). Three of these received metformin in the concentrations 95.4, 190.8, and $333.8 \mathrm{mg} / \mathrm{kg}$ body weight, respectively, representing $20 \%, 40 \%$, and $70 \%$ of LD 50 , in the form of i.p. injections in a $0.5 \mathrm{~mL}$ volume. The remaining two groups served as controls, one receiving the same volume in saline solution (negative control) and the other cyclophosphamide (Endoxan) $30 \mathrm{mg} / \mathrm{kg}$ (positive control).

The animals were sacrificed by cervical dislocation, twenty four hours after receiving the i.p. injections. Bonemarrow cells were then collected and washed with $3 \mathrm{~mL}$ of a phosphate buffer saline (PBS) solution containing 5 IU heparin $/ \mathrm{mL}$. After fixing the harvested cells three times in methanol-acetic acid (3:1), slides were prepared. These were then stained with $10 \%$ Giemsa. Two thousand polychromatic erythrocytes (PCEs) and two thousand normochromatic erythrocytes (NCEs) were examined per animal. Micronuclei were only scored in PCEs. The PCE/NCE relationship was recorded as a sign of cytotoxicity. Micronucleus assaying was according to MacGregor et al. (1987).

\section{Statistical analysis}

Statistical analysis of data from the in vivo test was based on micronucleated cells/group and analyzed by Chisquare test using Yates correction. Comet-assay data were analyzed taking into account two parameters, namely i) frequency of DNA damaged cells and ii) frequency of DNA damage (DD). Prior to statistical analysis, data were transformed into arcsine $\mathrm{x}(\mathrm{x}=$ number of cells with DNA damage) or $\log \mathrm{x}(\mathrm{x}=\mathrm{IDD})$. Transformed data (arcsine or $\log \mathrm{x})$ underwent variance analysis (ANOVA). The Fischer test was used in the event of statistically significant differences $(\mathrm{p}<0.05)$.
Table 1 - DNA damage in CHO-K1 cells exposed to metformin, as measured by comet assaying.

\begin{tabular}{lcc}
\hline Treatments & $\begin{array}{c}\text { Cell with DNA } \\
\text { damage }(\%)\end{array}$ & DNA damage (\%) \\
\hline Negative control & $24.53 \pm 13.08^{\mathrm{a}}$ & $16.26 \pm 7.18^{\mathrm{a}}$ \\
Positive control & $95.88 \pm 1.06^{\mathrm{b}}$ & $89.43 \pm 5.79^{\mathrm{c}}$ \\
Metformin $114.4 \mu \mathrm{g} / \mathrm{mL}$ & $86.77 \pm 4.72^{\mathrm{b}}$ & $64.12 \pm 7.03^{\mathrm{bc}}$ \\
Metformin $572.0 \mu \mathrm{g} / \mathrm{mL}$ & $73.77 \pm 12.46^{\mathrm{b}}$ & $41.74 \pm 9.23^{\mathrm{ab}}$ \\
\hline a, b, c Different superscripts in the same column denote significant differ- \\
ences $(\mathrm{p}<0.05)$.
\end{tabular}

\section{Results}

Compared to the control group, metformin at the lower concentration induced DNA damage in CHO-K1 cells (Table 1). However, although treated with both concentrations, the frequency of those with increased levels of DNA damage was higher when they were not dose-related. No chromosome aberrations were observed in metaphase cells at the treatment-levels used (Table 2).

The in vivo tests showed there to be no bone-marrow cells at the highest concentration $(333.9 \mathrm{mg} / \mathrm{kg})$, probably as a result of acute cytotoxicity, although without any clinical outcome, such as morbidity or mortality. Nonetheless, at the lower concentrations $(95.4 \mathrm{mg} / \mathrm{kg}$ and $190.8 \mathrm{mg} / \mathrm{kg})$, there was neither an increase in micronuclei nor a decrease in PCE frequency in viable cells (Table 3).

Table 3 - Micronuclei in polychromatic erythrocytes of Swiss mice treated with metformin*

\begin{tabular}{lcc}
\hline Treatments & MN - PCE (\%) & PCE/NCE (\%) \\
\hline Negative control & $3.5 \pm 2.70^{\mathrm{a}}$ & $45.51^{\mathrm{a}}$ \\
Positive control & $23.3 \pm 12.80^{\mathrm{b}}$ & $34.88^{\mathrm{a}}$ \\
Metformin 95.4 mg/kg & $7.7 \pm 7.20^{\mathrm{a}}$ & $46.11^{\mathrm{a}}$ \\
Metformin $190.8 \mathrm{mg} / \mathrm{kg}$ & $11.3 \pm 10.30^{\mathrm{a}}$ & $46.03^{\mathrm{a}}$ \\
\hline
\end{tabular}

MN: micronuclei; PCE: polychromatic erythrocytes; NCE: normochromatic erythrocytes *Metformin at concentrations of $334.7 \mathrm{mg} / \mathrm{kg}$ - there are no bone-marrow cells, probably as result of acute cytotoxicity. ${ }^{\mathrm{a}, \mathrm{b}}$ Different superscripts in the same column denote significant differences $(\mathrm{p}<0.05)$.

Table 2 - Chromosome aberrations in metaphase CHO-K1 cells exposed to metformin.

\begin{tabular}{|c|c|c|c|c|c|c|}
\hline \multirow[t]{2}{*}{ Treatments } & \multirow{2}{*}{$\begin{array}{l}\text { Examined cells } \\
\text { (N) }\end{array}$} & \multicolumn{3}{|c|}{ Structural chromosome aberrations (\%) } & \multirow{2}{*}{$\begin{array}{l}\text { Total structural } \\
\text { aberrations }(\%)\end{array}$} & \multirow{2}{*}{$\begin{array}{c}\text { Number of } \\
\text { damaged cells }\end{array}$} \\
\hline & & Breaks & Gaps & $\begin{array}{l}\text { Acentric frag- } \\
\text { ments }\end{array}$ & & \\
\hline Negative control & 400 & $0.50 \pm 0.50$ & $1.25 \pm 1.06$ & $2.75 \pm 0.35$ & $4.5 \pm 0.00^{\mathrm{a}}$ & 18 \\
\hline Positive control & 356 & $2.56 \pm 1.35$ & - & $9.24 \pm 0.60$ & $11.82 \pm 0.74^{\mathrm{b}}$ & 42 \\
\hline Metformin $114.4 \mu \mathrm{g} / \mathrm{mL}$ & 400 & $0.75 \pm 0.35$ & $0.75 \pm 1.06$ & $5.50 \pm 0.70$ & $6.50 \pm 2.82^{\mathrm{ab}}$ & 28 \\
\hline Metformin $572.0 \mu \mathrm{g} / \mathrm{mL}$ & 398 & $1.76 \pm 1.07$ & $0.25 \pm 0.35$ & $4.02 \pm 0.73$ & $6.03 \pm 1.46^{\mathrm{a}}$ & 32 \\
\hline
\end{tabular}

${ }^{a, b}$ Different superscripts in the same column denote significant differences $(p<0.05)$. 


\section{Discussion}

According to comet assaying, metformin was shown to induce DNA damage in CHO-K1 cells. However, this in vitro genotoxicity was not noted in chromosome aberrations and in vivo tests (micronucleus). Micronucleus assaying, as of chromosome aberrations, is a cytogenetic form that measures chromosomal damage, thus only effective when both DNA strands are broken. On the contrary, comet assaying quantitatively measures DNA strand breaks in either or both strands (Slamenova et al., 1997; Zeni and Scarfi, 2010).

The frequency of cells with DNA damage was higher when CHO-K1 cells were treated with both metformin concentrations, although the frequency of DNA-strand breaks was only perceived at the lower concentration (Table 1). It is presumed that cells treated with the higher concentration were severely damaged in the first cycle. Thus, the second cycle resulted in fewer cells capable of successfully repairing the damage. In fact, only moderate alterations were noted (comet type 1 and 2). Under stress conditions, such as DNA damage, p53 blocks the cell-cycle, thus facilitating DNA repair or inducing apoptosis. Therefore, CHO-cell deficiency in p53 might lead to the inefficient repair of cells damaged by substances, such as metformin. Furthermore, the failure to eliminate DNA damaged cells might give rise to morphologically and functionally altered cell-transformed cell clones. Buzzai et al. (2007) suggested that metformin is selectively toxic to p53-deficient cells. On other hand, the lower concentration did not induce cell-death in the first cycle. Thus, the expected changes were apparent in cells in the second cycle, i.e., the accumulated damage from both cycles showing 3 and 4 comet-types.

DNA damage can have biological consequences, such as transcription and/or replication inhibition, ultimately leading to cell-death (Olsen et al., 2005; Hales, 2005). Accumulation of DNA damage and unrepaired DNA lesions can cause cell-death or permanent cell-cycle blockage (Hassa and Hottiger, 2005). Therefore, it is reasonable to assume that those cells surviving the first cycle modulated the observed type of DNA damage. The association between drug exposure and DNA damage (and eventually apoptosis induction) has been established. Kefas et al. (2004) showed that longer metformin exposure ( $>24 \mathrm{~h}$ ) resulted in a progressive increase in apoptotic rat $\beta$-cells, the effects of metformin being both dose- and time-dependent. In fact, low concentrations of metformin are capable of inducing AMP-activated protein kinase (AMPK) mediated alterations in $\beta$-cells (Kefas et al., 2004). On the other hand, Ben Sahra et al. (2008) showed that, although not apoptosis inductive, metformin was effective in blocking the cellcycle in $\mathrm{G}_{0} / \mathrm{G}_{1}$.

So far, there has been no indication of chromosome aberrations induced by metformin in bone-marrow cells. According to the in vivo study, no micronuclei were ob- served in mice bone-marrow cells at concentrations of $95.4 \mathrm{mg} / \mathrm{kg}$ and $190.8 \mathrm{mg} / \mathrm{kg}$, although the higher concentration induced cytotoxicity. Twenty four hours after administration of metformin at $333.9 \mathrm{mg} / \mathrm{kg}$, no cells were found for micronucleus analysis. It is noteworthy that not only the dose, but also the type of tissue, can modulate genotoxicity, some substances possibly presenting pro- and anti- genotoxic effects. Bone marrow, easy to isolate and process, is routinely used in chromosome aberration tests. This highly vascular tissue has a population of rapidly cycling cells, thereby increasing vulnerability to toxic drugs. On the other hand, the lower metformin concentrations $(95.4 \mathrm{mg} / \mathrm{kg}$ and $190.8 \mathrm{mg} / \mathrm{kg}$ ) did not induce micronucleated cells. It is probable that, under the prevailing experimental conditions, metformin induces more breaks in a single strand of DNA, Thus, in the absence of double strands, no damage was detected by cytogenetic tests.

The mechanism of metformin effects on DNA molecules is unknown. Notwithstanding, these might possibly be mediated through its activation of AMPK, thereby increasing nitric oxide synthase (Zhou et al., 2001; Davis et al., 2006; Za'tara et al., 2008). Zou et al., (2004) speculated that mitochondria-derived reactive-nitrogen-species mediate AMPK activation by way of metformin. Depending on the dose, nitric oxide is capable of inducing beneficial effects by playing a role in the gene regulation and signal transduction pathways possibly involved in defensive mechanisms against oxidative stress (Miyamoto et al., 2003). Nevertheless, high levels (nanomoles) can damage macromolecules, such as lipids, proteins and DNA, thereby leading to mutagenesis and carcinogenesis (Bishop and Cashman, 2003). Moreover, it has been shown that nitric oxide can induce mutation by impairing the repair-enzyme system (Jaiswal et al., 2001). Metformin is known to accumulate in tissues. Studies have indicated that doses insufficient for lowering hyperglycemia in diabetic animals concentrate in tissues (Wilcock and Bailey, 1994). Hirsch et al., (2009) showed that low doses of metformin inhibits cellular transformation and selectively kills cancer-stem cells in four genetically different types of breast cancer. The authors propose combining metformin with chemotherapy as a novel treatment, not only for breast cancer, but possibly others. Furthermore, in vitro lymphocytes challenged with $\mathrm{CumOOH}$ showed that high concentrations of metformin potentially induce DNA damage (Onaran et al., 2006). Taken together, the data suggest that chronic metformin exposure may be potentially genotoxic. Thus, pregnant woman under treatment with metformin should be properly evaluated as to vulnerability to DNA damage.

\section{Acknowledgments}

Financial support from the Brazilian agencies, CNPq, CAPES, and FINATEC is gratefully acknowledged. 


\section{References}

Almeida Santos MF, Ferrari I and Luna H (2005) Chromosomal aberration analysis in workers exposed to chemical and biological hazards in research laboratories. Environ Res 97:330-334.

Anedda A, Rial E and González-Barroso MM (2008) Metformin induces oxidative stress in white adipocytes and raises uncoupling protein 2 levels. J Endocrinol 199:33-40.

Attia SM, Helal GK and Alhaider AA (2009) Assessment of genomic instability in normal and diabetic rats treated with metformin. Chem Biol Interact 180:296-304.

Barash HERG, Edrei Y, Ella E, Israel A, Cohen I, Corchia N, Ben-Moshe T, Pappo O, Pikarsky E, Goldenberg D, et al. (2010) Accelerated carcinogenesis following liver regeneration is associated with chronic inflammation-induced double-strand DNA breaks. Proc Natl Acad Sci USA 107:2207-2212.

Ben Sahra I, Laurent K, Loubat A, Giorgetti-Peraldi S, Colosetti P, Auberger P, Tanti JF, Le Marchand-Brustel Y and Bost F (2008) The antidiabetic drug metformin exerts an antitumoral effect in vitro and in vivo through a decrease of cyclin D1 level. Oncogene 27:3576-3586.

Bishop A and Cashman NR (2003) Induced adaptive resistance to oxidative stress in the CNS: A discussion on possible mechanisms and their therapeutic potential. Curr Drug Metab 4:171-184.

Brassard M, AinMelk Y and Baillargeon JP (2008) Basic infertility including polycystic ovary syndrome. Med Clin North Am 92:1163-1192.

Buzzai M, Jones RG, Amaravadi RK, Lum JJ, DeBerardinis RJ, ZhaoF, Viollet B and Thompson CB (2007) Systemic treatment with the antidiabetic drug metformin selectively impairs p53-deficient tumor cell growth. Cancer Res 67:67456752.

Davis BJ, Xie Z, Viollet B and Zou MH (2006) Activation of the AMP-activated kinase by antidiabetes drug metformin stimulates nitric oxide synthesis in vivo by promoting the association of heat shock protein 90 and endothelial nitric oxide synthase. Diabetes 55:496-505.

De Leo V, Musacchio MC, Morgante G, Piomboni P and Petraglia F (2006) Metformin treatment is effective in obese teenage girls with PCOS. Hum Reprod 21:2252-2256.

DePalo VA, Mailer K, Yoburn D and Crausman RS (2005) Lactic acidosis associated with metformin use in treatment of type 2 diabetes mellitus. Geriatrics 60:36 39-41.

Diehl LA, Fabris BA, Barbosa DS, De Faria EC, Wiechmann SL and Carrilho AJ (2008) Metformin increases HDL3-cholesterol and decreases subcutaneous truncal fat in nondiabetic patients with HIV-associated lipodystrophy. AIDS Patient Care STDS 22:779-786.

Hadigan C, Corcoran C, Basgoz N, Davis B, Sax P and Grinspoon S (2000) Metformin in the treatment of HIV lipodystrophy syndrome: A randomized controlled trial. JAMA 284:472477.

Hales BF (2005) DNA repair disorders causing malformations. Curr Opin Genet Dev 15:234-240.

Hassa PO and Hottiger MO (2005) An epigenetic code for DNA damage repair pathways? Biochem Cell Biol 83:270-285.

Hirsch HA, Iliopoulos D, Tsichlis PN and Struhl K (2009) Metformin selectively targets cancer stem cells, and acts together with chemotherapy to block tumor growth and prolong remission. Cancer Res 69:7507-7511.

Jaiswal M, LaRusso NF, Shapiro RA, Billiar TR and Gores GJ (2001) Nitric oxide-mediated inhibition of DNA repair potentiates oxidative DNA damage in cholangiocytes. Gastroenterology 120:190-199.

Jakubowicz DJ, Iuorno MJ, Jakubowicz S, Roberts KA and Nestler JE (2002) Effects of metformin on early pregnancy loss in the polycystic ovary syndrome. J Clin Endocrinol Metab 87:524-529.

Jaloszynski P, Kujawski M, Czub-Swierczek M, Markowska J and Szyfter K (1997) Bleomycin-induced DNA damage and its removal in lymphocytes of breast cancer patients studied by comet assay. Mutat Res 385:223-233.

Janjetovic K, Harhaji-Trajkovic L, Misirkic-Marjanovic M, Vucicevic L, Stevanovic D, Zogovic N, Sumarac-Dumanovic M, Micic D and Trajkovic V (2011). Eur J Pharmacol 668:373382.

Johnson JA, Simpson SH, Toth EL and Majumdar SR (2005) Reduced cardiovascular morbidity and mortality associated with metformin use in subjects with type 2 diabetes. Diabet Med 22:497-502.

Kefas BA, Cai Y, Kerckhofs K, Ling Z, Marten G, Heimberg H, Pipeleers D and Van de Casteele M (2004) Metformininduced stimulation of AMP-activated protein kinase in beta-cells impairs their glucose responsiveness and can lead to apoptosis. Biochem Pharmacol 68:409-416.

Lilja AE and Mathiesen ER (2006) Polycystic ovary syndrome and metformin in pregnancy. Acta Obstet Gynecol Scand 85:861-868.

MacGregor JT, Heddle JA, Hite M, Margalin BH, Ramel C, Salamone MF, Tice RR and Will D (1987) Guidelines for the conduct of micronucleus assay in mammalian bone morrow erythrocytes. Mutat Res 189:103-112.

Miyamoto Y, Koh YH, Park YS, Fujiwara N, Sakiyama H, Misonou Y, Ookawara T, Suzuki K, Honke K and Taniguchi N (2003) Oxidative stress caused by inactivation of glutathione peroxidase and adaptive responses. Biol Chem 384:567-574.

Moustacchi E (2000) DNA damage and repair: Consequences on dose-responses. Mutat Res 464:35-40.

Nisbet JC, Sturtevant JM and Prins JB (2004) Metformin and serious adverse effects. Med J Aust 180:53-54.

Olsen AK, Lindeman B, Wiger R, Duale N and Brunborg G (2005) How do male germ cells handle DNA damage? Toxicol Appl Pharmacol 207:521-531.

Onaran I, Guven GS, Ozdas SB, Kanigur G and Vehid S (2006) Metformin does not prevent DNA damage in lymphocytes despite its antioxidant properties against cumene hydroperoxide-induced oxidative stress. Mutat Res 611:1-8.

Rotella CM, Monami M and Mannucci E (2006) Metformin beyond diabetes: New life for an old drug. Curr Diabetes Rev 2:307-315.

Singh NP, McCoy MT, Tice RR and Schneider EL (1988) A simple technique for quantitation of low levels of DNA damage in individual cells. Exp Cell Res 175:184-191.

Slamenova D, Gabelova A, Ruzekova L, Chalupa I, Horvathova E, Farkasova T, Bozsakyova E and Stetina R (1997) Detection of MNNG-induced DNA lesions in mammalian cells; validation of comet assay against DNA unwinding tech- 
nique, alkaline elution of DNA and chromosomal aberrations. Mutat Res 383:243-252.

Snyder RW and Berns JS (2004) Use of insulin and oral hypoglycemic medications in patients with diabetes mellitus and advanced kidney disease. Semin Dial 17:365-370.

Spiller HA and Sawyer TS (2006) Toxicology of oral antidiabetic medications. Am J Health Syst Pharm 63:929-938.

Strack T (2008) Metformin: A review. Drugs Today (Barc) 44:303-314.

Tankova T, Dakovska L, Kirilov G and Koev D (2003) Metformin in the treatment of obesity in subjects with normal glucose tolerance. Rom J Intern Med 41:269-275.

Visvardis EE, Tassiou AM and Piperakis SM (1997) Study of DNA damage induction and repair capacity of fresh and cryopreserved lymphocytes exposed to $\mathrm{H}_{2} \mathrm{O}_{2}$ and gammairradiation with the alkaline comet assay. Mutat Res 383:71-80.

Wilcock C and Bailey CJ (1994) Accumulation of metformin by tissues of the normal and diabetic mouse. Xenobiotica $24: 49-57$
Za'tara G, Bar-Tana J, Kalderon B, Suter M, Morad E, Samovski D, Neumann D and Hertz R (2008) AMPK activation by long chain fatty acyl analogs. Biochem Pharmacol 76:1263-1275.

Zeni O and Scarfi MR (2010) DNA damage by carbon nanotubes using the single cell gel electrophoresis technique. Methods Mol Biol 625:109-119.

Zhou G, Myers R, Li Y, Chen Y, Shen X, Fenyk-Melody J, Wu M, Ventre J, Doebber T, Fujii N, et al. (2001) Role of AMPactivated protein kinase in mechanism of metformin action. J Clin Invest 108:1167-1174.

Zou MH, Kirkpatrick SS, Davis BJ, Nelson JS, Wiles WG, Schlattner U, Neumann D, Brownlee M, Freeman MB and Goldman MH (2004) Activation of the AMP-activated protein kinase by the anti-diabetic drug metformin in vivo. Role of mitochondrial reactive nitrogen species. J Biol Chem 279:43940-43951.

Associate Editor: Daisy Maria F. Salvadori

License information: This is an open-access article distributed under the terms of the Creative Commons Attribution License, which permits unrestricted use, distribution, and reproduction in any medium, provided the original work is properly cited. 